\title{
PRODUK EKSPOR PROSPEKTIF INDONESIA KE PERU DAN FAKTOR-FAKTOR PENENTU ALIRAN PERDAGANGANNYA KE KAWASAN AMERIKA SELATAN
}

\author{
Dewi Setyawati ${ }^{1}$, Rina Oktaviani ${ }^{2}$, Tanti Novianti ${ }^{2}$ \\ ${ }^{1}$ Mahasiswa Program Magister Sekolah Pascasarjana Program Studi Ilmu Ekonomi IPB \\ ${ }^{2}$ Staf Pengajar FEM IPB
}

Artikel diterima Agustus 2014

Artikel disetujui untuk dipublikasikan Desember 2014

\begin{abstract}
Peru in South America area has potential market for Indonesia's products and has been established as prospective market. This study is aimed to analyze the performance of bilateral trading between Indonesia and Peru, to analyze the export products prospective for Indonesia-Peru bilateral trading and also the factors affecting its trade flow to South America. The analysis methods used in this research were Revealed Comparative Advantage (RCA), Export Product Dynamic (EPD), Intra Industry Trade (IIT) and gravity model. Gravity model used panel data with modification sample cross section data of South America countries (Peru, Argentina, Brazil, Chili, Ecuador, Colombia, Paraguay, Suriname, Uruguay and Venezuela) from 2000-2013 time series. The result showed that trade balance as indicator of performance in bilateral trading Indonesia-Peru have been increasing. Indonesia's export product prospective to Peru are HS 4001 (Natural rubber, balata, gutta-percha etc), HS 0801 (Brazil nuts, cashew nuts \& coconuts), HS 5509 (Yarn of synth staple fibre, not put for retail sale), and HS 4420 (Wood marquetry \& inlaid wood; caskets \& cases or cutlery of wood). Only HS 5509 (Yarn of synth staple fibre,not put for retail sale) and HS 0801 (Brazil nuts, cashew nuts \& coconuts) have weak integration. The gravity model with Fixed Effect Model showed that different GDP per capita and trade/GDP have significant positive effect on value export of product prospective. Tariff have significant negative effect for HS 0801 (Brazil nuts, cashew nuts \& coconuts), HS 5509 (Yarn of synth staple fibre, not put for retail sale) dan HS 4420 (Wood marquetry \& inlaid wood; caskets \& cases or cutlery of wood). Economic distances have significant negative effect exclude HS 4001 (Natural rubber, balata, gutta-percha etc). Real exchange rate have significant possitive only for HS 5509 (Yarn of synth staple fibre,not put for retail sale), while the others product have not significant effect.
\end{abstract}

Keywords : Indonesia-Peru-South America Trading, RCA, EPD, IIT, Gravity model

\section{PENDAHULUAN}

Ekspor Indonesia masih didominasi oleh ekspor non migas (minyak bumi dan gas). Pada tahun 2013 ekspor non migas memberikan kontribusi lebih tinggi (82,13\%) dibandingkan dengan ekspor migas $(17,87 \%)$. Data Kementerian Perdagangan menunjukkan bahwa pada tahun tersebut Republik Rakyat Tiongkok (RRT) menjadi negara tujuan 
ekspor non migas terbesar Indonesia dengan nilai ekspor sebesar US \$18,92 miliar atau sebesar $13,88 \%$ dari total ekspor non migas Indonesia. Negara tujuan ekspor non migas setelah RRT berturut-turut adalah Jepang dengan nilai ekspor sebesar US \$14,68 miliar $(10,77 \%)$, Amerika Serikat dengan nilai ekspor sebesar US \$ 13,79 miliar $(10,12 \%)$, India dengan nilai ekspor sebesar US \$11,87 miliar $(8,71 \%)$ dan Singapura sebesar US \$ 9,37 miliar $(6,88 \%)$.

Krisis global yang melanda sejumlah negara maju telah menimbulkan pengaruh dalam aktivitas perdagangan internasional negara berkembang, termasuk Indonesia. Hal ini karena umumnya negara berkembang mengekspor sebagian besar komoditi lokalnya ke negara maju. Penurunan daya beli masyarakat di negara-negara maju tersebut memberikan implikasi menurunnya impor barang sehingga potensi peluang ekspor yang tersedia juga kecil. Salah satu upaya pemerintah Indonesia mengatasi masalah tersebut adalah melakukan diversifikasi pasar ke pasar prospektif yaitu pasar negara-negara berkembang atau pasar non-tradisional (emerging markets). Penetapan suatu negara menjadi pasar prospektif berdasarkan nilai pertumbuhan ekspor yang tinggi serta nilai dan pangsa pasar ekspor Indonesia yang terus meningkat dengan trend perdagangan positif dalam lima tahun terakhir. Peru merupakan salah satu negara yang ditetapkan sebagai pasar prospektif (Kementerian Perdagangan 2012).

Kontribusi ekspor Indonesia ke Peru menunjukkan trend yang semakin meningkat dalam periode tahun 20092013. Ekspor Indonesia ke Peru pada tahun 2009 senilai US \$ 51,17 juta dan memberikan kontribusi sebesar 0,044\% terhadap total ekspor Indonesia ke dunia. Sedangkan pada tahun 2013 ekspor Indonesia ke Peru senilai US \$ 178.45 juta dan kontribusinya mencapai $0,098 \%$ terhadap total ekspor Indonesia ke dunia. Apabila dibandingkan dengan negaranegara di kawasan Amerika Selatan, peningkatan ekspor Indonesia ke Peru memberikan trend tertinggi sebesar 22,78\% (Tabel 1).

Tabel 1 Kontribusi Peru dan negara-negara di kawasan Amerika Selatan terhadap total ekspor Indonesia tahun 2009-2013 (dalam \%)

\begin{tabular}{lllllllc}
\hline No & Negara & $\mathbf{2 0 0 9}$ & $\mathbf{2 0 1 0}$ & $\mathbf{2 0 1 1}$ & $\mathbf{2 0 1 2}$ & $\mathbf{2 0 1 3}$ & Trend/tahun \\
\hline 1 & Peru & 0,044 & 0,060 & 0,080 & 0,084 & 0,098 & 22,786 \\
2 & Argentina & 0,136 & 0,178 & 0,174 & 0,165 & 0,184 & 8,580 \\
3 & Bolivia & 0,003 & 0,002 & 0,003 & 0,004 & 0,003 & $(0,256)$ \\
4 & Brazil & 0,763 & 0,969 & 0,853 & 0,782 & 0,830 & 3,213 \\
5 & Chili & 0,143 & 0,122 & 0,105 & 0,092 & 0,094 & $(9,853)$ \\
6 & Equador & 0,032 & 0,043 & 0,044 & 0,043 & 0,045 & 9,248 \\
8 & Guyana & 0,001 & 0,001 & 0,001 & 0,002 & 0,001 & 18,018 \\
10 & Colombia & 0,073 & 0,075 & 0,069 & 0,090 & 0,072 & 1,574 \\
11 & Paraguay & 0,012 & 0,016 & 0,001 & 0,010 & 0,010 & $(1,498)$ \\
12 & Suriname & 0,004 & 0,003 & 0,002 & 0,004 & 0,003 & $(1,063)$ \\
13 & Uruguay & 0,011 & 0,019 & 0,022 & 0,020 & 0,016 & 16,535 \\
14 & Venezuela & 0,033 & 0,041 & 0,063 & 0,051 & 0,034 & 6,281 \\
\hline & Amerika Selatan & 1,254 & 1,528 & 1,424 & 1,345 & 1,388 & 3,168 \\
\hline
\end{tabular}

Sumber : diolah dari UN COMTRADE 2014 
Peru dalam dekade terakhir merupakan negara paling sukses mencapai pertumbuhan ekonomi berkelanjutan di bawah demokrasi politik, dapat mengurangi setengah dari kemiskinan dan meningkatkan kelompok ekonomi kelas menengah baru. Peningkatan ekonomi Peru tersebut didukung oleh aktivitas ekspor, kebijakan makro ekonomi dan komitmen yang kuat terhadap perdagangan internasional (Sanborn dan Yong 2013). Indikator-indikator di atas menunjukkan bahwa Peru merupakan negara dengan peluang pasar ekspor yang cukup baik bagi Indonesia dan kondisi ini menjadi alasan pemilihan Peru sebagai subjek kajian penelitian.

Peru diharapkan juga mampu menjadi salah satu pintu masuk bagi ekspor Indonesia ke negara di kawasan Amerika Selatan yang lain. Menurut Portocarrero (2013), letak Peru yang sangat baik di Amerika secara alami menjadi negara penghubung di kawasan Amerika Selatan. Peru memiliki bandar udara dan pelabuhan laut terbaik di kawasan. Pelabuhan laut Callao yang saat ini sedang dalam perluasan merupakan pelabuhan paling dinamis di kawasan. Selain itu, pengembangan proyek Inisiatif Integrasi Infrastruktur Regional Amerika Selatan (IIRSA) akan menjadikan Peru sebagai sebuah jembatan yang efisien dalam menghubungkan pasar Amerika Selatan, Asia dan Amerika Serikat.

Perdagangan ekspor dan impor Peru lebih dari $90 \%$ dilakukan melalui perjanjian perdagangan bebas atau Free Trade Agreement (Portocarrero 2013). Kondisi ini dapat menjadi satu kendala bagi ekspor Indonesia untuk bersaing karena tidak semua produk dikenakan pajak impor sebesar nol persen, seperti halnya negara yang sudah melakukan perjanjian perdagangan bebas dengan Peru.
Diplomasi perdagangan Indonesia dengan Peru telah dilakukan sebagai salah satu instrumen penting dalam memperjuangkan akses pasar. Kerjasama bilateral Indonesia dan Peru saat ini masih dalam tahapan Preferential Trade Agreement (PTA) ${ }^{1}$ yang merupakan salah satu bentuk dalam implementasi Free Trade Agreement (FTA). Pertemuan bilateral Indonesia-Peru untuk penandatanganan Memorandum of Understanding (MoU) on Trade Promotion Activities dilaksanakan pada tanggal 10 Juli 2012.

Kajian terkait dengan potensi komoditas yang memiliki keunggulan dan daya saing ke pasar Peru masih diperlukan untuk pengembangan perdagangan ekspor, sehingga dapat menjadi persiapan bagi Indonesia dalam rangka penerapan PTA dengan Peru. Selain itu perlu dilihat faktor-faktor yang memengaruhi aliran perdagangan komoditas unggulan tersebut untuk kawasan Amerika Selatan.

Tujuan penelitian ini adalah (1) Menganalisis performa perdagangan bilateral antara Indonesia dan Peru, (2) Menganalisis produk ekspor yang prospektif dikembangkan oleh Indonesia ke Peru serta integrasi perdagangannya, (3) Menganalisis faktor-faktor yang memengaruhi aliran perdagangan produk ekspor prospektif dari Indonesia ke kawasan Amerika Selatan.

\section{METODE}

\section{Jenis dan Sumber Data}

Data yang digunakan dalam penelitian ini seluruhnya berupa data

\footnotetext{
1 PTA dibentuk antara dua atau lebih negara dengan mereduksi tarif pada barang tertentu selama perdagangan antara negara tersebut. Meskipun tarif tidak dipindahkan dengan lengkap, jumlah yang dikenakan tarif lebih sedikit daripada pengenaan tarif yang diberlakukan untuk luar negara yang tidak melakukan perjanjian.
} 
sekunder dengan sumber data seperti pada Tabel 2. Sumber data terkait dengan ekspor, impor dan neraca perdagangan berasal dari United Nations Commodity Trade Statistics Database dan IFS (International Finance Statistic) yang dikeluarkan oleh World Bank.

Data yang terkait dengan Gross Domestik Product (GDP), populasi, diperoleh dari World Development Indicator (WDI) yang dikeluarkan oleh World Bank. Data nilai tukar nominal serta Indek Harga Konsumen (IHK) atau Consumer Price Index (CPI) untuk penghitungan nilai tukar riil berasal dari IFS World Bank.

Tabel 2 Jenis dan sumber data

\begin{tabular}{|c|c|}
\hline Data & Sumber \\
\hline $\begin{array}{l}\text { Data ekspor, impor, } \\
\text { neraca perdagangan (US } \\
\$ \text { \$) }\end{array}$ & $\begin{array}{l}\text { UN COMTRADE, } \\
\text { IFS World Bank }\end{array}$ \\
\hline GDP per kapita (US \$) & WDI World Bank \\
\hline $\begin{array}{l}\text { Nilai Tukar Riil (Rp/local } \\
\text { current unit) }\end{array}$ & IFS World Bank \\
\hline IHK atau CPI & IFS World Bank \\
\hline $\begin{array}{l}\text { Applied average tariff } \\
(\%)\end{array}$ & WTO \\
\hline $\begin{array}{l}\text { Jarak antar ibukota } \\
\text { negara }(\mathrm{km})\end{array}$ & CEPII \\
\hline
\end{tabular}

Data tarif berupa nilai applied average tariff berasal dari World Trade Organization (WTO). Sedangkan jarak geografis antara ibukota negara Indonesia dengan negara importir di kawasan Amerika Selatan bersumber dari Centre d'Etudes Prospectives et d'Informations Internationales (CEPII).

Data perdagangan yang digunakan dalam model gravity adalah data Harmonize System (HS) empat digit. Ketersediaan data yang terbatas dalam analisis model gravity diatasi dengan menggunakan data time series dan cross section yang berbeda untuk masingmasing model produk ekspor. Penyesuaian data yang digunakan untuk analisis model gravity tersebut secara rinci dapat dilihat pada Tabel 10 bagian pembahasan hasil.

\section{Metode Analisis}

Performa atau keragaan perdagangan bilateral Indonesia Peru dianalisis secara deskriptif. Indikator yang digunakan untuk melihat performa perdagangan adalah tingkat pertumbuhan ekspor, impor dan neraca perdagangan.

Analisis pengembangan produk potensial dilakukan dengan menggunakan alat analisis Revealed Comparative Advantage (RCA) dan Export Product Dynamic (EPD). Produk ekspor prospektif Indonesia yang dikembangkan ke Peru dipilih lima (5) produk berdasarkan kedua analisis tersebut. Setelah itu dilihat derajat integrasi menggunakan analisis Intra Industry Trade.

\section{Metode Analisis RCA}

Variabel RCA yang diukur dalam penelitian ini adalah kinerja ekspor Indonesia ke Peru dengan menghitung pangsa nilai ekspor Indonesia terhadap total ekspor ke negara Peru, kemudian dibandingkan dengan pangsa nilai ekspor dunia ke negara Peru. Dalam bentuk matematis, RCA untuk masing-masing produk $\mathrm{k}$ yang diekspor oleh Indonesia ke Peru dapat dituliskan :

$\mathrm{RCA}_{\mathrm{ek}}=\frac{X_{e k} / X_{e}}{W_{p k} / W_{p}}$

dimana:

$\mathrm{X}_{\mathrm{ek}}=$ Nilai ekspor produk $\mathrm{k}$ dari Indonesia ke Peru

$\mathrm{X}_{\mathrm{e}}=$ Nilai ekspor total dari Indonesia ke Peru

$\mathrm{W}_{\mathrm{pk}}=$ Nilai ekspor produk $\mathrm{k}$ dari dunia ke Peru

$\mathrm{W}_{\mathrm{p}}=$ Nilai ekspor total dari dunia ke Peru.

Jika nilai RCA produk tertentu lebih besar dari satu (1), maka Indonesia memiliki keunggulan komparatif di atas rata-rata dunia untuk 
produk tersebut. Sebaliknya apabila lebih kecil dari satu (1), keunggulan komparatif Indonesia untuk komoditas tersebut tergolong rendah. Semakin besar nilai indeks RCA suatu produk, semakin tinggi pula tingkat keunggulan komparatifnya. Data yang digunakan untuk analisis RCA berasal dari UN COMTRADE tahun 2001-2013.

Penetapan produk prospektif dilakukan dengan menyeleksi produk yang memiliki nilai RCA sepuluh tertinggi untuk ekspor Indonesia ke Peru pada periode tahun 2001-2013. Nilai RCA masing-masing produk dirata-ratakan dalam periode waktu analisis. Penggunaan nilai rata-rata dengan alasan bahwa tidak semua produk diekspor sepanjang periode tahun analisis sehingga dengan membuat rata-rata sepanjang periode dapat mengakomodir kondisi tersebut.

\section{Metode Analisis EPD}

Setelah diperoleh sepuluh produk yang memiliki nilai RCA tertinggi dilakukan analisis menggunakan matriks EPD. Matriks EPD terdiri atas daya tarik pasar dan informasi kekuatan bisnis. Kombinasi dari daya tarik pasar dan kekuatan bisnis ini menghasilkan karakter posisi dari produk yang ingin dianalisis ke dalam empat kategori, yaitu "rising star", "falling star", "lost opportunity" dan "retreat". Mengacu pada Gambar 1, produk yang diestimasi akan menempati salah satu dari empat kuadran berdasarkan nilai daya tarik pasar dan kekuatan bisnis produk tersebut.

Sumbu X pada Gambar 1 menggambarkan pertumbuhan pangsa pasar ekspor Indonesia ke Peru sebagai informasi kekuatan bisnis yang merupakan perhitungan nilai ekspor produk $k$ dari Indonesia ke Peru $\left(X_{e k}\right)$ dibagi dengan nilai ekspor produk $k$ dari dunia ke Peru $\left(W_{p k}\right)$. Secara matematis dapat dituliskan :

SumbuX =

$$
\frac{\sum_{t=1}^{t}\left(\frac{X_{i n}}{X_{n}}\right)_{t} \times 100 \%-\sum_{t=1}^{t}\left(\frac{X_{i n}}{X_{n}}\right)_{t-1} \times 100 \%}{T}
$$

Sedangkan sumbu $\quad \mathrm{Y}$ menggambarkan pertumbuhan pangsa pasar ekspor produk $\mathrm{k}$ dalam perdagangan Indonesia ke Peru sebagai daya tarik pasar yang merupakan perhitungan nilai ekspor produk $k$ dari dunia ke Peru $\left(W_{p k}\right)$ dibagi dengan nilai total ekspor dunia ke Peru $\left(W_{p}\right)$. Secara matematis dapat dituliskan :

Sumbu Y =

$$
\frac{\sum_{t=1}^{t}\left[\frac{W_{p k}}{W_{p}}\right]_{t} x 100 \%-\sum_{t=1}^{t}\left[\frac{W_{p k}}{W_{p}}\right]_{t-1} x 100 \%}{T}
$$

Dimana $\mathrm{T}$ merupakan jumlah periode tahun analisis, $t$ menunjukkan tahun ke- $t$ dan $\mathrm{k}$ adalah jenis produk.

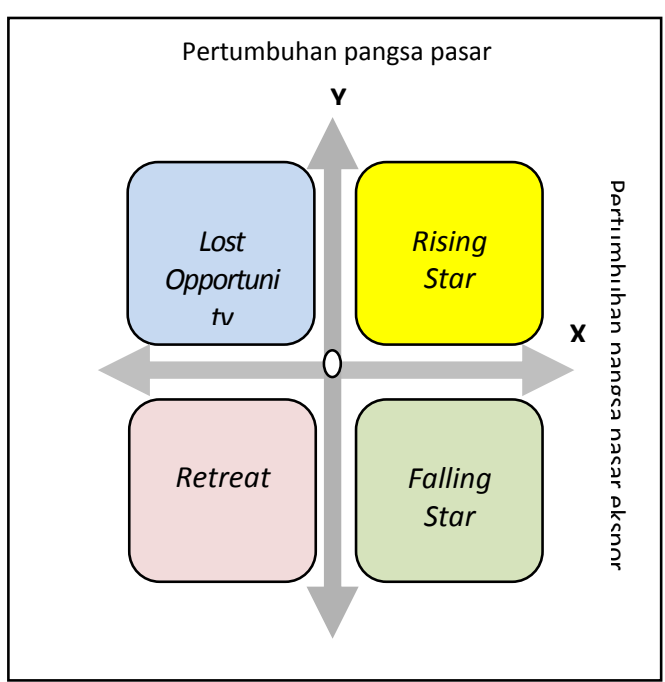

Sumber : Esterhuizen 2006

Gambar 7 Daya tarik pasar dan kekuatan bisnis pada EPD

Posisi pasar ideal adalah yang mempunyai pangsa pasar tertinggi ekspor sebagai "rising star". Posisi ini menunjukkan bahwa negara tersebut memperoleh tambahan pangsa pasar yang tumbuh cepat (fast-growing products). 
Posisi paling tidak diinginkan adalah "lost opportunity" yang terkait dengan penurunan pangsa pasar produk yang dinamis. "Falling star"merupakan posisi yang tidak disukai, namun lebih baik jika dibandingkan dengan "lost opportunity" karena pangsa pasarnya tetap meningkat. Sementara itu, "retreat" biasanya tidak diinginkan, tetapi pada kasus tertentu 'mungkin' diinginkan jika pergerakannya menjauhi produk-produk yang stagnan dan menuju produk-produk yang dinamik (Esterhuizen 2006).

\section{Metode Analisis IIT}

Analisis Intra Industry Trade dalam penelitian ini digunakan untuk menganalisis tingkat integrasi perdagangan antara Indonesia dan Peru. Pengukuran IIT dilakukan dengan menghitung nilai IIT lima produk ekspor prospektif yang telah ditentukan. Formulasi indikator yang digunakan untuk menganalisis IIT masingmasing produk $\mathrm{k}$ untuk ekspor dan impor dari Indonesia ke Peru menggadopsi Grubel-Lloyd Index dengan rumus:

$$
\mathrm{IIT}_{\mathrm{k}, \mathrm{ep}}=1-\frac{\left|X_{k, e p}-M_{k, e p}\right|}{X_{k, e p}+M_{k, e p}} \times 100 \%
$$

Dimana $X_{k, e p}$ merupakan nilai ekspor produk $\mathrm{k}$ dari Indonesia ke Peru dan $\mathrm{M}_{\mathrm{k}, \mathrm{ep}}$ adalah nilai impor produk $\mathrm{k}$ dari Indonesia ke Peru.

Indeks tersebut mempunyai nilai antara 0 sampai 100 (Tabel 3). Apabila semua transaksi perdagangan seimbang, maka indeks akan bernilai 100. Sebaliknya apabila semua transaksi perdagangan bersifat searah (one-way trade), maka indeks bernilai 0 . Dengan demikian, apabila nilai indeks semakin mendekati 100 berarti semakin besar pula peranan perdagangan intra industri. Apabila ekspor dan impor sama besar, maka perdagangan intra industri untuk negara tersebut mencapai tingkat yang maksimal (IIT=1). Data ekspor dan impor dengan kode HS empat digit yang digunakan bersumber dari UN COMTRADE.
Tabel 3 Klasifikasi Nilai IIT

\begin{tabular}{ll}
\hline Intra Industry Trade & \multicolumn{1}{c}{ Klasifikasi } \\
\hline$*$ & $\begin{array}{l}\text { Tidak terdapat aliran } \\
\text { perdagangan } \\
\text { Tidak terjadi integrasi } \\
\text { (one-way trade) }\end{array}$ \\
0,00 & Integrasi lemah \\
$0,00>24,99$ & Integrasi sedang \\
$25,00-49,99$ & Integrasi agak kuat \\
$50,00-74,99$ & Integrasi kuat \\
$75,00-99,99$ &
\end{tabular}

Sumber : Austria 2004

\section{Metode Analisis Model Gravity}

Analisis faktor penentu aliran perdagangan produk ekspor prospektif Indonesia ke Peru diperluas menjadi aliran perdagangan antara Indonesia ke wilayah Amerika Selatan. Hal ini dilakukan dengan pertimbangan (1) Peru dapat menjadi pintu masuk bagi ekspor Indonesia ke kawasan Amerika Selatan, (2) adanya keterbatasan time series data apabila dilakukan analisis bilateral Peru dan Indonesia. Keterbatasan data ini diatasi dengan menambahkan cross section data berupa negara-negara importir di kawasan Amerika Selatan sehingga analisis yang digunakan adalah model gravity panel data statis.

$$
\text { Variabel-variabel yang }
$$

digunakan dalam model dalam penelitian ini mengacu pada Shepherd (2013), Zarzoso dan Lehmann (2003), serta Rahman (2009) dengan beberapa penyesuaian variabel yang digunakan seperti pada persamaan berikut :

$$
\begin{aligned}
& \text { In ExportValue } \\
& \text { Dift }=\beta_{0}+\beta_{1} \ln \\
& \text { Tariff }_{\text {ikt }}+\beta_{4} \text { Trade/GDP } \\
& \text { EcoDistance }_{i t}+\varepsilon_{i t}
\end{aligned}
$$

Keterangan:

$\begin{aligned} \text { ExportValue }_{\mathrm{ikt}}= & \begin{array}{l}\text { Nilai ekspor nominal } \\ \text { produk prospektif k dari } \\ \text { Indonesia ke negara } \\ \text { importir i pada tahun } \mathrm{t}\end{array} \\ & (\text { US \$). } \\ \text { DiffGDPCapit }_{i t}= & \begin{array}{l}\text { Perbedaan Gross Domestic } \\ \text { Product Nominal Per }\end{array}\end{aligned}$




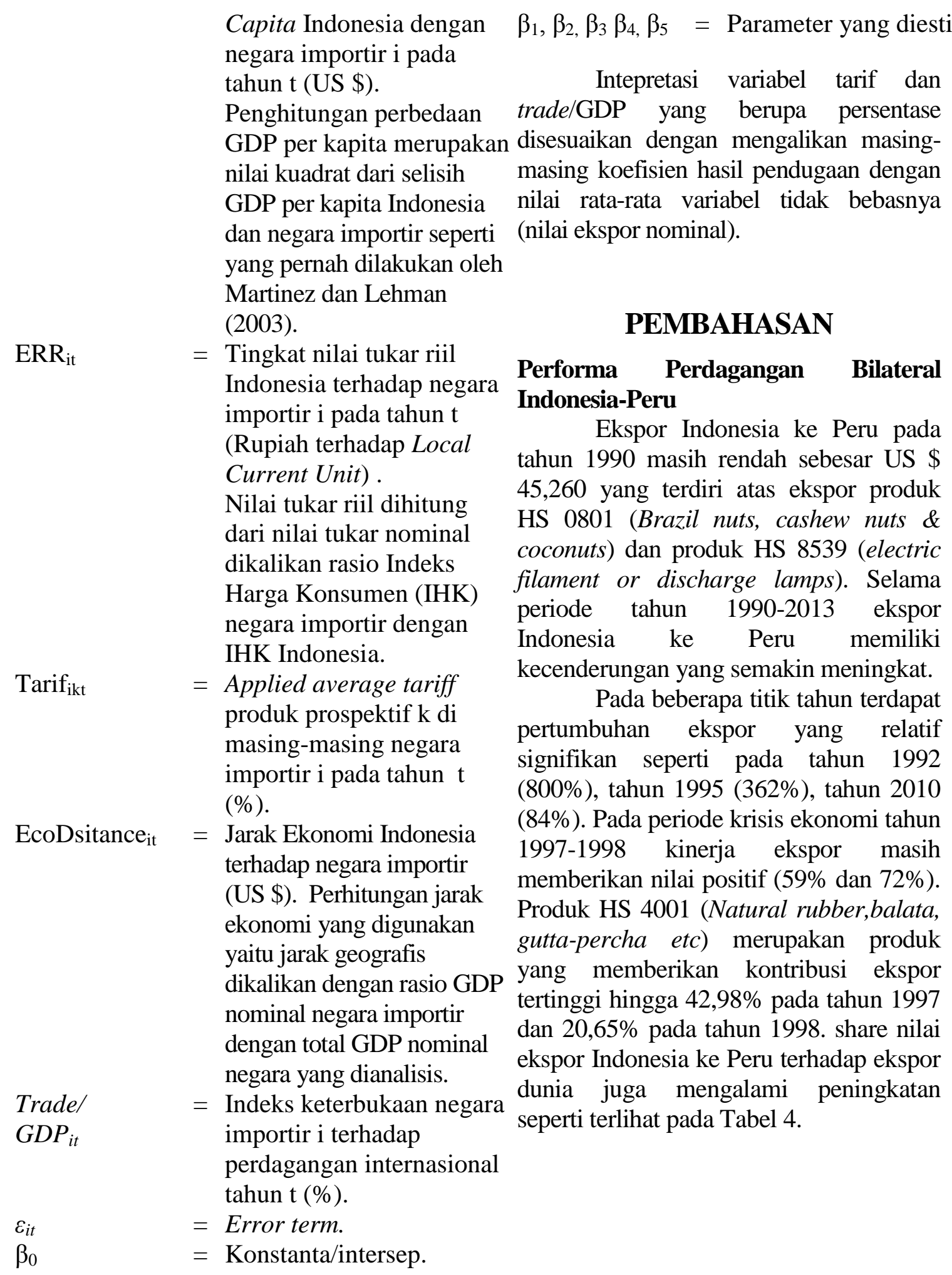


Tabel 4 Performa Perdagangan Bilateral Indonesia dan Peru tahun 1990-2013

\begin{tabular}{|c|c|c|c|c|c|c|c|c|}
\hline \multirow[b]{2}{*}{ Tahun } & \multicolumn{3}{|c|}{ Ekspor Indonesia ke Peru } & \multicolumn{3}{|c|}{ Impor Indonesia dari Peru } & \multirow[b]{2}{*}{$\begin{array}{l}\text { Total ekspor } \\
\text { dan Impor } \\
\text { (000 US \$) } \\
(\mathrm{X}+\mathrm{M})\end{array}$} & \multirow[b]{2}{*}{$\begin{array}{c}\text { Neraca } \\
\text { perdagangan } \\
(000 \text { US \$) } \\
(\mathrm{X}-\mathrm{M})\end{array}$} \\
\hline & $\begin{array}{l}\text { Nilai ekspor } \\
\text { (000 US\$) } \\
\text { (X) }\end{array}$ & $\begin{array}{l}\text { Pertum } \\
\text { buhan } \\
(\%)\end{array}$ & $\begin{array}{c}\text { Share } \\
\text { thdp } \\
\text { ekspor } \\
\text { dunia } \\
(\%)\end{array}$ & $\begin{array}{l}\text { Nilai impor } \\
\text { (000 US \$) } \\
\text { (M) }\end{array}$ & $\begin{array}{c}\text { Pertumbuhan } \\
(\%)\end{array}$ & $\begin{array}{c}\text { Share } \\
\text { thdp } \\
\text { impor } \\
\text { dunia } \\
(\%)\end{array}$ & & \\
\hline 1990 & 45,26 & & 0,000 & 3409,75 & & 0,016 & 3455,01 & $(3364,49)$ \\
\hline 1991 & 163,98 & 262,30 & 0,001 & 2434,39 & $-28,61$ & 0,009 & 2598,36 & $(2270,41)$ \\
\hline 1992 & 1475,79 & 800,01 & 0,004 & 776,29 & $-68,11$ & 0,003 & 2252,08 & 699,51 \\
\hline 1993 & 1230,91 & $-16,59$ & 0,003 & 15330,10 & 1874,80 & 0,054 & 16561,00 & $(14099,19)$ \\
\hline 1994 & 3316,82 & 169,46 & 0,008 & 40485,69 & 164,09 & 0,127 & 43802,51 & $(37168,86)$ \\
\hline 1995 & 15311,73 & 361,64 & 0,034 & 33133,34 & $-18,16$ & 0,082 & 48445,07 & $(17821,62)$ \\
\hline 1996 & 10029,84 & $-34,50$ & 0,020 & 41087,83 & 24,01 & 0,096 & 51117,66 & $(31057,99)$ \\
\hline 1997 & 15905,35 & 58,58 & 0,030 & 42372,67 & 3,13 & 0,102 & 58278,02 & $(26467,32)$ \\
\hline 1998 & 27344,29 & 71,92 & 0,056 & 13200,73 & $-68,85$ & 0,048 & 40545,02 & 14143,55 \\
\hline 1999 & 19457,40 & $-28,84$ & 0,040 & 26448,99 & 100,36 & 0,110 & 45906,39 & $(6991,60)$ \\
\hline 2000 & 21603,10 & 11,03 & 0,035 & 41092,93 & 55,37 & 0,123 & 62696,03 & $(19489,84)$ \\
\hline 2001 & 21221,00 & $-1,77$ & 0,038 & 45604,92 & 10,98 & 0,147 & 66825,92 & $(24383,92)$ \\
\hline 2002 & 25103,00 & 18,29 & 0,044 & 27840,15 & $-38,95$ & 0,089 & 52943,15 & $(2737,15)$ \\
\hline 2003 & 22192,00 & $-11,60$ & 0,036 & 19495,55 & $-29,97$ & 0,060 & 41687,55 & 2696,45 \\
\hline 2004 & 25205,00 & 13,58 & 0,035 & 25775,72 & 32,21 & 0,055 & 50980,72 & $(570,72)$ \\
\hline 2005 & 27839,00 & 10,45 & 0,032 & 36422,21 & 41,30 & 0,063 & 64261,21 & $(8583,21)$ \\
\hline 2006 & 34400,00 & 23,57 & 0,034 & 31175,27 & $-14,41$ & 0,051 & 65575,27 & 3224,73 \\
\hline 2007 & 42145,00 & 22,51 & 0,037 & 27971,51 & $-10,28$ & 0,038 & 70116,51 & 14173,49 \\
\hline 2008 & 49851,00 & 18,28 & 0,036 & 38641,99 & 38,15 & 0,030 & 88492,99 & 11209,01 \\
\hline 2009 & 51172,00 & 2,65 & 0,044 & 36472,28 & $-5,61$ & 0,038 & 87644,28 & 14699,72 \\
\hline 2010 & 94180,00 & 84,05 & 0,060 & $, 31457,26$ & $-13,75$ & 0,023 & 125637,26 & 62722,74 \\
\hline 2011 & 161983,00 & 71,99 & 0,080 & 51388,62 & 63,36 & 0,029 & 213371,62 & 110594,38 \\
\hline 2012 & 159888,00 & $-1,29$ & 0,084 & 72679,00 & 41,43 & 0,038 & 232567,00 & 87209,00 \\
\hline 2013 & 178450,73 & 11,61 & 0,098 & 51801,15 & $-28,73$ & 0,028 & 230251,89 & 126649,58 \\
\hline
\end{tabular}

Sumber : UN COMTRADE 2014

Nilai impor pada periode 19902013 lebih berfluktuasi dibandingkan nilai ekspor. Pada tahun 1992 pada saat kinerja ekspor mengalami peningkatan yang signifikan, kinerja impor justru mengalami penurunan hingga $68 \%$. Pertumbuhan impor kemudian meningkat tajam pada tahun 1993 sebesar $1875 \%$. Produk HS 2301 (flour etc of meat meat offal fish crust etc unfit for human consumption) memberikan kontribusi terbesar dalam impor pada tahun 1993 yaitu 96,22\%. Sedangkan pada saat terjadinya krisis tahun 19971998 impor mengalami penurunan akibat melemahnya nilai tukar rupiah terhadap dolar.

Neraca perdagangan bilateral Indonesia dan Peru pada periode tahun 1990-2005 memiliki nilai positif dan negatif sehingga perkembangannya berfluktuatif. Perkembangan yang positif terdapat pada beberapa titik seperti pada tahun 1992, 1998 dan 2003.

Pada periode tahun 2006-2013 neraca perdagangan bilateral Indonesia 
dan Peru menunjukkan trend yang meningkat serta bernilai positif. Hal ini memberikan indikasi bahwa kinerja ekspor dapat terus ditingkatkan untuk memberikan nilai trade balance yang positif. Perdagangan bilateral Indonesia ke Peru pada periode 1990-2013 secara rinci dapat dilihat pada Tabel 4 .

Perdagangan antara Indonesia dan Peru yang telah dilakukan selama ini masih didominasi oleh ekspor impor komoditas non migas. Neraca perdagangan selama periode 2009-2013 menunjukkan bahwa hanya pada tahun 2012 terdapat ekspor non migas senilai US \$ 240 ribu (Kementerian Perdagangan 2014).

\section{Produk Ekspor Prospektif Indonesia Ke Peru}

\section{Hasil Analisis RCA}

Jumlah produk yang diperdagangkan pada tahun 2001- 2013 mencapai 357 produk dengan jumlah per tahun yang berfluktuasi (Gambar 2). Fluktuasi terjadi karena ada beberapa produk yang baru mulai dilakukan ekspor pada tahun tertentu dan ada pula yang pada tahun tertentu tidak dilakukan ekspor.

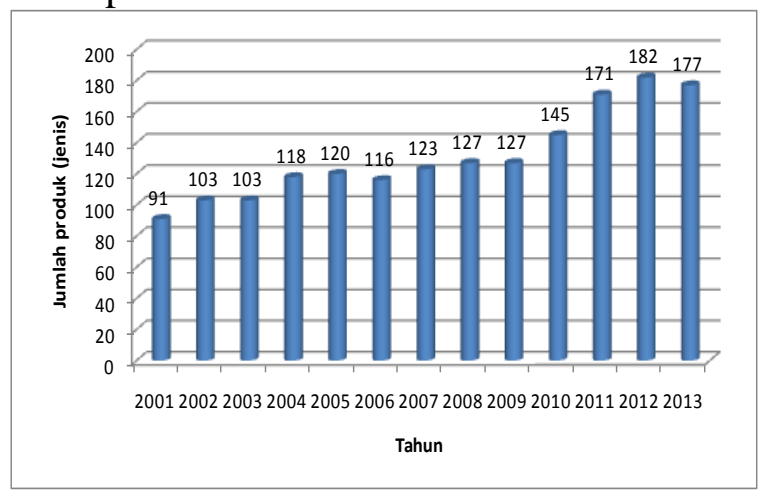

Sumber : diolah dari data UN COMTRADE 2014

Gambar 2 Fluktuasi jumlah produk yang diekspor dari Indonesia ke Peru periode tahun 2001-2013 (produk)
Analisis dengan metode RCA dilakukan untuk mengetahui produk yang prospektif diperdagangkan oleh Indonesia ke Peru. Hasil analisis menunjukkan pada tahun 2001-2012 sebanyak 51,75\% produk yang diekspor ke Peru tidak berdaya saing karena memiliki nilai RCA kurang dari 1. Selebihnya sebanyak $48,25 \%$ produk sudah memiliki daya saing dengan nilai RCA lebih dari 1 .

Sepuluh produk ekspor prospektif Indonesia ke Peru berdasarkan urutan nilai RCA tertinggi yaitu HS 4001 (Natural rubber balata gutta-percha etc), HS 4809 (Carbon self-copy paper etc roll of width > $36 \mathrm{~cm}$ ), HS 0801 (Brazil nuts cashew nuts \& coconuts), HS 5509 (Yarn of synth staple fibre not put for retail sale), HS 2927 (Diazo- azoor azoxycompounds), HS 4420 (Wood marquetry \& inlaid wood; caskets \& cases or cutlery of wood), HS 5513 (Woven fab of syn stapl fib $<85 \%$ of such fiber) mixed with cotton), HS 0301 (Live fish), HS 8506 (Primary cells and primary batteries), HS 1513 (Coconut (copra) palm kernel/babassu oil \& their fractions). Tabel 5 secara rinci memperlihatkan nilai RCA masing-masing produk prospektif ekspor dari Indonesia ke Peru.

\section{Hasil Analisis EPD}

Hasil analisis EPD menunjukkan sebagian besar produk masih memiliki pangsa pasar yang tinggi. Hal ini dapat terlihat bahwa kelompok produk rising star sebagai posisi pasar ideal memiliki pangsa pasar tertinggi ekspor sebesar $60,56 \%$. Terdapat $14,08 \%$ produk yang masuk dalam posisi pasar falling star. Pada kelompok produk ini pangsa pasar ekspor Indonesia di Peru masih bagus namun pangsa pasar kelompok produk ini sudah mengalami penurunan.

Sebanyak $19,72 \%$ produk ekspor Indonesia ke Peru yang masuk dalam kelompok loss opportunities. Produk ini memberi indikasi bahwa pangsa pasar ekspor Indonesia di Peru 
sudah menurun, namun pangsa pasar untuk produk ini masih memiliki peluang yang baik untuk dikembangkan. Sedangkan sebanyak $5,63 \%$ produk masuk dalam kuadran retreat yang menunjukkan bahwa kelompok produk ini memiliki pangsa pasar yang rendah.

Pemilihan lima komoditas prospektif dilakukan dengan menggabungkan sepuluh produk yang memiliki nilai RCA tertinggi pada analisis RCA sebelumnya, serta hasil analisis EPD yang tidak berada dalam kelompok retreat. Penetapan produk prospektif juga mempertimbangkan adanya ketersediaan data yang akan digunakan untuk analisis selanjutnya.
Ketersediaan data dalam analisis EPD dan model gravity menjadi hambatan untuk menganalisis lebih lanjut beberapa potensi produk. Produk HS 2927 (Diazo-azoor azoxycompounds) dan HS 1513 (Coconut palm kernel/babassu oil \& their fractions) tidak dapat dilakukan analisis EPD karena tidak ada ketersediaan data yang lengkap selama periode analisis EPD tahun 2008-2012. Sedangkan HS 0301 (live fish) tidak dapat dianalisis lebih lanjut untuk aliran perdagangan menggunakan model gravity karena adanya keterbatasan dalam panel data.

Tabel 5 Gabungan hasil analisis RCA dan Export Product Dynamic

\begin{tabular}{|c|c|c|c|c|c|}
\hline HS & Produk & RCA & EPD & $\begin{array}{l}\text { Ketersedi } \\
\text { a-an data }\end{array}$ & Terpilih \\
\hline 4001 & Natural rubber balata gutta-percha etc & 95,975 & $\mathrm{RS}$ & $\checkmark$ & $\checkmark$ \\
\hline 4809 & $\begin{array}{l}\text { Carbon self-copy paper etc roll of width }>36 \\
\mathrm{~cm}\end{array}$ & 83,818 & LO & $\checkmark$ & $\checkmark$ \\
\hline 0801 & Brazil nuts cashew nuts \& coconuts & 59,327 & $\mathrm{RS}$ & $\checkmark$ & $\checkmark$ \\
\hline 5509 & Yarn of synth staple fibre not put for retail sale & 58,505 & $\mathrm{RS}$ & $\checkmark$ & $\checkmark$ \\
\hline 2927 & Diazo- azoor azoxy-compounds & 47,115 & $*$ & $X$ & \\
\hline 4420 & $\begin{array}{l}\text { Wood marquetry \& inlaid wood; caskets \& } \\
\text { cases or cutlery of wood }\end{array}$ & 40,039 & FS & $\checkmark$ & $\checkmark$ \\
\hline 5513 & $\begin{array}{l}\text { Woven fab of syn stapl fib (<85\% of such fiber) } \\
\text { mixed with cotton }\end{array}$ & 35,948 & RT & $\checkmark$ & \\
\hline 0301 & Live fish & 33,984 & FS & $\mathrm{X}$ & \\
\hline 8506 & Primary cells and primary batteries & 32,664 & RT & $\checkmark$ & \\
\hline 1513 & $\begin{array}{l}\text { Coconut palm kernel/babassu oil \& their } \\
\text { fractions }\end{array}$ & 32.477 & $*$ & $X$ & \\
\hline
\end{tabular}

*) Data tidak tersedia untuk periode analisis

Sumber : diolah dari data sekunder 2014

Berdasarkan pertimbangan di atas maka ditetapkan lima produk prospektif yang akan dianalisis lebih lanjut yaitu HS 4001 (Natural rubber balata gutta-percha etc), HS 4809 (Carbon self-copy paper etc roll of width > $36 \mathrm{~cm}$ ), HS 0801 (Brazil nuts cashew nuts \& coconuts), HS 5509 (Yarn of synth staple fibre not put for retail sale) dan HS 4420 (Wood marquetry \& inlaid wood; caskets \& cases or cutlery of wood). Hasil analisis
RCA dan EPD pada sepuluh produk prospektif Indonesia Peru dapat dilihat pada Tabel 5.

Produk HS 4001 (Natural rubber balata gutta-percha etc) memiliki nilai RCA tertinggi dan berada pada kuadran rising star. Hasil ini mendukung Memorandum of Understanding bidang pertanian antara Indonesia-Peru pada tangga 17 Oktober 2013 yang menyatakan bahwa ekspor 
utama produk pertanian Indonesia ke Peru adalah karet alam. Peru merupakan salah satu negara yang bergantung pada ekspor karet Indonesia. (Kementerian Pertanian, 2013). Perjanjian yang ditandatangani saat KTT APEC tersebut berlaku selama 5 tahun.

Rata-rata pertumbuhan impor Peru terhadap lima produk ekspor prospektif Indonesia pada periode tahun 2009-2013 cukup baik sehingga dapat menjadi peluang pangsa pasar potensial (Tabel 6).

Indonesia berada pada posisi dua besar ekportir ke Peru untuk produk HS
4011 (Natural rubber balata guttapercha etc) setelah Guatemala, produk HS 4809 (Carbon self-copy paper etc roll of width > $36 \mathrm{~cm}$ ) setelah China, produk HS 0801 (Brazil nuts cashew nuts \& coconuts) setelah Brazil dan produk HS 5509 (Yarn of synth staple fibre not put for retail sale) setelah India. Sedangkan untuk produk HS 4420 (Wood marquetry \& inlaid wood; caskets \& cases or cutlery of wood) Indonesia menempati posisi ketiga sebagai eksportir terbesar setelah China dan India.

Tabel 6 Rata-rata kontribusi lima eksportir terbesar dan pertumbuhan impor Peru terhadap lima produk ekspor prospektif Indonesia tahun 2009-2013 (\%)

\begin{tabular}{|c|c|c|c|}
\hline HS & Produk & $\begin{array}{l}\text { Rata-rata kontribusi lima eksportir } \\
\text { terbesar untuk setiap produk }\end{array}$ & $\begin{array}{l}\text { Rata-rata } \\
\text { pertumbuhan } \\
\text { impor Peru }\end{array}$ \\
\hline 4011 & $\begin{array}{l}\text { Natural rubber balata } \\
\text { gutta-percha etc }\end{array}$ & $\begin{array}{l}\text { Guatemala }(59,63) \text { Indonesia }(\mathbf{1 2 , 7 7}) \\
\text { Vietnam }(10,16) \text { Ecuador }(6,52) \text { Malaysia } \\
(5,06)\end{array}$ & 31,52 \\
\hline 4809 & $\begin{array}{l}\text { Carbon self-copy paper etc } \\
\text { roll of width }>36 \mathrm{~cm}\end{array}$ & $\begin{array}{l}\text { China }(54,49) \text { Indonesia }(\mathbf{1 7 , 3 4 )} \text { Amerika } \\
\text { Serikat }(12,57) \text { Brazil }(11,43) \text { Jerman } \\
(1,9)\end{array}$ & 17,15 \\
\hline 0801 & $\begin{array}{l}\text { Brazil nuts cashew nuts \& } \\
\text { coconuts }\end{array}$ & $\begin{array}{l}\text { Brazil }(47,22) \text { Indonesia }(31,63) \text { Bolivia } \\
(9,20) \text { Philiphina }(7,37) \text { Malaysia }(2,95)\end{array}$ & 57,45 \\
\hline 5509 & $\begin{array}{l}\text { Yarn of synth staple fibre not } \\
\text { put for retail sale }\end{array}$ & $\begin{array}{l}\text { India }(49,09) \text { Indonesia }(\mathbf{1 7 , 9 3}) \text { China } \\
(16,25) \text { Vietnam }(6,80) \text { Thailand }(5,11)\end{array}$ & 27,36 \\
\hline 4420 & $\begin{array}{l}\text { Wood marquetry \& inlaid } \\
\text { wood; caskets \& cases or } \\
\text { cutlery of wood }\end{array}$ & $\begin{array}{l}\text { China }(71,27) \text { India }(5,61) \text { Indonesia } \\
(\mathbf{5 , 1 9 )} \text { Vietnam }(2,14) \text { Colombia }(1,88)\end{array}$ & 30,26 \\
\hline
\end{tabular}

Sumber : diolah dari data UN COMTRADE 2014

\section{Hasil Analisis IIT}

Nilai IIT per produk dianalisis dengan menggunakan data tahun 20082013. Berdasarkan pada hasil analisis hanya sekitar $12,64 \%$ produk yang memiliki integrasi perdagangan (dengan asumsi jumlah produk HS empat digit sebesar 182 produk). Produk ekspor Indonesia ke Peru tidak semuanya memiliki integrasi setiap tahunnya, sehingga dapat dikatakan bahwa produkproduk yang diperdagangkan secara bilateral masih belum terdiferensiasi dan belum memanfaatkan peningkatan skala ekonomi.

Produk yang memiliki integrasi sedang sampai integrasi kuat sebagian besar masuk dalam tekstil dan produk tekstil. Peningkatan nilai tambah melalui pengembangan industri manufaktur merupakan salah satu implikasi untuk meningkatkan nilai IIT. Grimwade (2000) menyatakan bahwa intra industry trade lebih tinggi pada sektor manufaktur karena produksi dilakukan dengan mempertimbangkan economies of scale. 
Analisis IIT terhadap sepuluh produk ekspor prospektif periode tahun 2008-2013 menunjukkan bahwa sebagian besar produk belum terintegrasi. Hanya produk HS 5509 (Yarn of synth staple fibre not put for retail sale) yang memiliki nilai IIT sebesar 13,21\% pada tahun 2012 dan 5,00\% pada tahun 2013. Selain itu terdapat integrasi pada produk HS 0801 (Brazil nuts cashew nuts \& coconuts) sebesar 4,00\% pada tahun 2013. Nilai IIT tersebut juga masih tergolong memiliki integrasi yang lemah.
Kondisi tersebut memberikan gambaran bahwa perdagangan produk ekspor prospektif antara Indonesia dan Peru masih berlangsung satu arah. Konsep keunggulan komparatif model Ricardian, serta endowment factor model Hechseler Ohlin lebih mendominasi dalam analisis produk ekspor prospektif Indonesia ke Peru. Hasil analisis niai IIT untuk sepuluh produk ekspor prospektif Indonesia Peru dapat dilihat pada Tabel 7.

Tabel 7 Nilai IIT berdasarkan nilai RCA sepuluh produk potensi ekspor Indonesia tahun 2008-2013

\begin{tabular}{|c|c|c|c|c|c|c|c|}
\hline Kode HS & Produk & 2008 & 2009 & 2010 & 2011 & 2012 & 2013 \\
\hline 4001 & Natural rubber balata gutta-percha etc & 0 & 0 & 0 & 0 & 0 & 0 \\
\hline 4809 & $\begin{array}{l}\text { Carbon self-copy paper etc roll of width > } \\
36 \mathrm{~cm}\end{array}$ & 0 & 0 & 0 & 0 & 0 & 0 \\
\hline 0801 & Brazil nuts cashew nuts \& coconuts & 0 & 0 & 0 & 0 & 0 & 0,04 \\
\hline 5509 & $\begin{array}{l}\text { Yarn of synth staple fibre not put for retail } \\
\text { sale }\end{array}$ & 0 & 0 & 0 & 0 & 0,13 & 0,05 \\
\hline 2927 & Diazo- azoor azoxy-compounds & 0 & 0 & 0 & $*$ & $*$ & $*$ \\
\hline 4420 & $\begin{array}{l}\text { Wood marquetry \& inlaid wood; caskets \& } \\
\text { cases or cutlery of wood }\end{array}$ & 0 & 0 & 0 & 0 & 0 & 0 \\
\hline 5513 & $\begin{array}{l}\text { Woven fab of syn stapl fib }(<85 \% \text { of such } \\
\text { fiber) mixed with cotton }\end{array}$ & 0 & 0 & 0 & 0 & 0 & 0 \\
\hline 0301 & Live fish & 0 & 0 & 0 & 0 & 0 & 0 \\
\hline 8506 & Primary cells and primary batteries & 0 & 0 & 0 & 0 & 0 & 0 \\
\hline 1513 & $\begin{array}{l}\text { Coconut (copra) palm kernel/babassu oil \& } \\
\text { their fractions }\end{array}$ & $*$ & $*$ & * & 0 & * & 0 \\
\hline
\end{tabular}

Sumber : diolah dari UN COMTRADE 2014

*) tidak ada keterkaitan

Faktor-Faktor yang Memengaruhi Aliran Perdagangan Produk Ekspor Prospektif Indonesia Peru ke Kawasan Amerika Selatan

Analisis aliran perdagangan lima produk ekspor prospektif dari Indonesia ke Peru selanjutnya diperluas ke kawasan Amerika Selatan. Model gravity digunakan untuk melihat aliran perdagangan ini. Gambaran negara sampel di kawasan Amerika Selatan yang melakukan impor lima produk ekspor prospektif Indonesia-Peru dapat dilihat pada Tabel 8 .

Peru merupakan importir terbesar di kawasan Amerika Selatan untuk produk HS 4809 (Carbon self-copy paper etc roll of width $>36 \mathrm{~cm}$ ) dari Indonesia. Sedangkan untuk empat produk prospektif yaitu HS 4011 (Natural rubber balata gutta-percha etc), HS 0801 (Brazil nuts cashew nuts \& coconuts), HS 5509 (Yarn of synth staple fibre not put for retail sale) dan HS 4420 (Wood marquetry \& inlaid 
wood; caskets \& cases or cutlery of wood,) Brazil merupakan importir terbesar dari Indonesia di kawasan Amerika Selatan. Walaupun bukan merupakan importir utama untuk empat produk prospektif ekspor, namun Peru memberikan kontribusi yang potensial untuk menjadi tujuan pasar non tradisional. Selain itu masih dapat diharapkan Peru menjadi pintu masuk bagi ekspor Indonesia di kawasan Amerika Selatan.

Tabel 8 Negara importir lima produk ekspor prospektif Indonesia-Peru di kawasan Amerika Selatan dan rata-rata kontribusinya terhadap total ekspor Indonesia ke dunia periode 2009-2013 (\%)

\begin{tabular}{|c|c|c|}
\hline HS & Produk & $\begin{array}{l}\text { Negara Importir dan rata-rata kontribusi terhadap total } \\
\text { ekspor Indonesia ke dunia setiap produk }\end{array}$ \\
\hline 4011 & $\begin{array}{l}\text { Natural rubber balata } \\
\text { gutta-percha etc }\end{array}$ & $\begin{array}{l}\text { Brazil (3.58) Argentina (1.14) Colombia }(0.26) \text { Venezuela } \\
(0.26) \text { Peru (0.07) Ecuador }(0.15) \text { Chile }(0.07)\end{array}$ \\
\hline 4809 & $\begin{array}{l}\text { Carbon self-copy paper } \\
\text { etc roll of width }>36 \mathrm{~cm}\end{array}$ & $\begin{array}{l}\text { Peru (3.57) Colombia (2.74) Ecuador }(2.44) \text { Chili }(1.53) \\
\text { Brazil (0.71) Argentina (0.44) Uruguay (0.18) Paraguay (0.08) } \\
\text { Venezuela (0.06) Suriname }(0.03)\end{array}$ \\
\hline 0801 & $\begin{array}{l}\text { Brazil nuts cashew nuts } \\
\text { \& coconuts }\end{array}$ & $\begin{array}{l}\text { Brazil (18.39) Argentina (7.88) Uruguay (6.12) Paraguay } \\
\text { (2.36) Peru (2.09) Chili (1.68) Colombia (0.68) Venezuela } \\
(0.01)\end{array}$ \\
\hline 5509 & $\begin{array}{l}\text { Yarn of synth staple fibre } \\
\text { not put for retail sale }\end{array}$ & $\begin{array}{l}\text { Brazil (14.90) Argentina (2.61) Colombia (1.96) Venezuela } \\
(0.80) \text { Peru (0.38) Ecuador (0.15) Uruguay (0.06) Paraguay } \\
(0.03) \text { Suriname }(0.001)\end{array}$ \\
\hline 4420 & $\begin{array}{l}\text { Wood marquetry \& inlaid } \\
\text { wood; caskets \& cases or } \\
\text { cutlery of wood }\end{array}$ & $\begin{array}{l}\text { Brazil (0.84) Chili (0.69) Argentina }(0.46) \text { Colombia }(0.22) \\
\text { Venezuela (0.12) Uruguay (0.11) Peru (0.07) Ecuador }(0.02) \\
\text { Suriname (0.01) Paraguay }(0.004) .\end{array}$ \\
\hline
\end{tabular}

Sumber : diolah dari data UN COMTRADE 2014

Beberapa variabel yang dimasukkan dalam model diturunkan dari indikator makro. Sebagai contoh variabel GDP per kapita merupakan gambaran indikator GDP dan populasi. Indikator Consumer Price Index (CPI) digunakan untuk melihat nilai tukar riil, sedangkan rasio total ekspor impor dan GDP menjadi pendekatan untuk mengukur indeks keterbukaan perdagangan. Gambaran indikator makro Indonesia dan sampel negara di kawasan Amerika Selatan pada tahun 2013 dapat dilihat pada Tabel 9.

Tabel 9 Indikator makro Indonesia dan negara sampel di kawasan Amerika Selatan tahun 2013

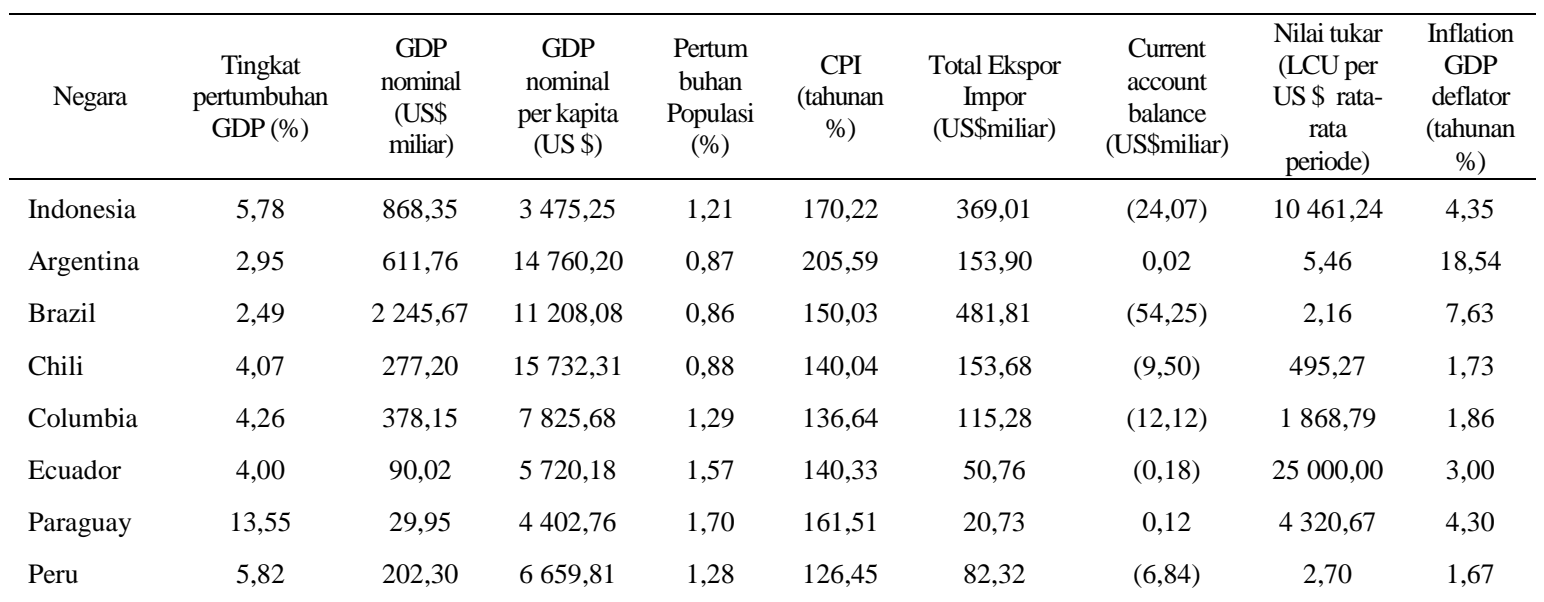




\begin{tabular}{lccccccccc}
\hline Negara & $\begin{array}{c}\text { Tingkat } \\
\text { pertumbuhan } \\
\text { GDP }(\%)\end{array}$ & $\begin{array}{c}\text { GDP } \\
\text { nominal } \\
\text { (US\$ } \\
\text { miliar) }\end{array}$ & $\begin{array}{c}\text { GDP } \\
\text { nominal } \\
\text { per kapita } \\
\text { (US \$) }\end{array}$ & $\begin{array}{c}\text { Pertum } \\
\text { buhan } \\
\text { Populasi } \\
(\%)\end{array}$ & $\begin{array}{c}\text { CPI } \\
\text { (tahunan } \\
\%)\end{array}$ & $\begin{array}{c}\text { Total Ekspor } \\
\text { Impor } \\
\text { (US\$miliar) }\end{array}$ & $\begin{array}{c}\text { Current } \\
\text { account } \\
\text { balance } \\
\text { (US\$miliar) }\end{array}$ & $\begin{array}{c}\text { Nilai tukar } \\
\text { (LCU per } \\
\text { US rata- } \\
\text { rata } \\
\text { periode) }\end{array}$ & $\begin{array}{c}\text { Inflation } \\
\text { GDP } \\
\text { deflator } \\
\text { (tahunan } \\
\%)\end{array}$ \\
\hline Suriname & 4,44 & 5,23 & 9699,87 & 0,88 & 182,67 & 4,31 & 0,24 & 3,30 & $(0,07)$ \\
Uruguay & 4,40 & 55,71 & 16350,73 & 0,35 & 179,84 & 20,84 & $(2,63)$ & 20,48 & 7,62 \\
Venezuela & 1,34 & 438,28 & 14414,75 & 1,49 & 627,80 & 155,81 & 11,02 & 6,05 & 59,93 \\
\hline
\end{tabular}

Sumber : WDI dan IFS , World Bank 2014

Terdapat lima model menjelaskan faktor-faktor yang memengaruhi aliran perdagangan secara terpisah. Terdapat empat model yang merujuk pada persamaan 5. Pengecualian dilakukan untuk model produk HS 0801 (Brazil nuts cashew nuts \& coconuts) yang tidak memasukkan variabel keterbukaan perdagangan (Trade/GDP) sebagai variabel bebas. Hal ini dilakukan karena adanya keterbatasan data cross section yang menjadi retriksi dalam penentuan jumlah variabel.

Penyesuaian terhadap data panel dilakukan karena terdapat keterbatasan data. Data time series untuk produk HS 4420 (Wood marquetry \& inlaid wood; caskets \& cases or cutlery of wood) menggunakan data periode tahun 20002013 (14 tahun). Sedangkan empat produk ekspor prospektif yang lain menggunakan data periode tahun 20032013 (11 tahun).

Data cross section berupa data negara-negara di kawasan Amerika Selatan yang melakukan perdagangan bilateral dengan Indonesia untuk masing-masing produk secara berkelanjutan pada periode waktu yang dianalisis. Negara yang terletak di kawasan Amerika Selatan berjumlah 14 negara (www.wikipedia.com), namun data cross section dalam penelitian ini untuk masing-masing produk ekspor prospektif secara rinci dapat dilihat pada Tabel 10.

Tabel 10 Penyesuaian data time series dan cross section untuk model gravity

\begin{tabular}{lcl}
\hline Kode HS (Produk) & Data time series & \multicolumn{1}{c}{ Data cross section } \\
\hline 4001 (Natural rubber...) & $2003-2013$ & $\begin{array}{l}\text { Peru, Brazil, Chli, Ecuador, Colombia, } \\
\text { Venezuela } \\
\text { Peru, Argentina, Chili, Ecuador, Colombia, } \\
\text { Uruguay } \\
4809 \text { (Carbon self...) }\end{array}$ \\
$2003-2013$ & $\begin{array}{l}\text { Peru, Argentina, Brazil, Chili, Uruguay } \\
\text { Peru, Argentina, Brazil, Chili, Ecuador, } \\
\text { Colombia, Uruguay }\end{array}$ \\
5509 (Brazil nuts...) & $2003-2013$ & $\begin{array}{l}\text { Peru, Argentina, Brazil, Chili, Ecuador, } \\
\text { Colombia, Uruguay, Venezuela, Suriname }\end{array}$ \\
4420 (Wood & $2003-2013$ & \\
marquetry...) & $2000-2013$ &
\end{tabular}

Hasil estimasi koefisien variabel pada panel data model gravity tersebut diolah dengan menggunakan program software Eviews 6. Penggunaan metode panel data dalam penelitian ini didasarkan pada kondisi sampel karena data time series untuk menganalisis nilai aliran perdagangan produk ekspor prospektif hanya memiliki rentang waktu yang terbatas yaitu maksimal 14 tahun.

Berdasarkan nilai Hausman Test, metode Fixed Effect Model (FEM) 
terpilih sebagai metode untuk menganalisis kelima model. Hasil analisis ini telah diperkuat dengan menggunakan metode pembobotan yaitu weighted SUR (Seemingly Unrelated Regression) dalam meregresi data panel.

Hasil uji kecocokan model (goodness of fit) berdasar nilai koefisien determinasi $\left(\mathrm{R}^{2}\right)$ menunjukkan bahwa lima model memiliki $\mathrm{R}^{2}$ di atas $90 \%$. Hasil estimasi tersebut berarti bahwa variasi peubah-peubah bebas dalam model mampu menjelaskan perubahan nilai ekspor sebesar $92,61 \%$ untuk produk
HS 4001 (Natural rubber balata guttapercha etc); 94,93\% untuk HS 4809 (Carbon self-copy paper etc roll of width $>36 \mathrm{~cm}) ; 96,21 \%$ untuk produk HS 0801 (Brazil nuts cashew nuts \& coconuts) ; 97,67\% untuk produk HS 5509 (Yarn of synth staple fibre not put for retail sale) dan 94,46\% untuk produk HS 4420 (Wood marquetry \& inlaid wood); sedangkan masing-masing sisanya diterangkan oleh faktor-faktor lain yang tidak terdapat dalam model. Hasil estimasi dapat dilihat pada Tabel 11.

Tabel 11 Hasil estimasi faktor-faktor yang memengaruhi aliran perdagangan masingmasing produk ekspor prospektif Indonesia ke Amerika Selatan

\begin{tabular}{lccccc}
\hline Variabel & \multicolumn{5}{c}{ Produk } \\
\cline { 2 - 6 } & $\begin{array}{c}\text { HS 4001 } \\
(\text { Natural } \\
\text { rubber...) }\end{array}$ & $\begin{array}{c}\text { HS 4809 } \\
\text { (Carbon self- } \\
\text { copy paper..) }\end{array}$ & $\begin{array}{c}\text { HS 0801 } \\
\text { (Brazil nuts } \\
\text { cashew nuts.. }\end{array}$ & $\begin{array}{c}\text { HS 5509 } \\
\text { (Yarn of synth } \\
\text { staple fibre } \\
\text { DiffGDPCap }\end{array}$ & $\begin{array}{c}\text { HS 4420 } \\
\text { (Wood } \\
\text { marquetry \& } \\
\text { inlaid wood...) }\end{array}$ \\
\hline ERR & $0,475^{* *}$ & $0,239^{* *}$ & $0,817^{* *}$ & $0,576^{* *}$ & $0,407 * *$ \\
& $(0,000)$ & $(0,001)$ & $(0,000)$ & $(0,000)$ & $(0,000)$ \\
Tariff & $-0,599$ & $2,519^{* *}$ & $-0,365$ & $0,749^{* *}$ & $-0,072$ \\
& $(0,258)$ & $(0,000)$ & $(0,244)$ & $(0,006)$ & $(0,632)$ \\
Trade/GDP & 0,182 & $-0,011$ & $-0,052^{* *}$ & $-0,043^{* *}$ & $-0,040^{* *}$ \\
& $(0,115)$ & $(0,478)$ & $(0,000)$ & $(0,034)$ & $(0,016)$ \\
EcoDistance & $0,044 * *$ & 0,004 & & $0,021^{* *}$ & $0,010^{*}$ \\
& $(0,000)$ & $(0,737)$ & & $(0,000)$ & $(0,060)$ \\
C & 0,299 & $-3,032^{* *}$ & $-2,884 * *$ & $-1,365^{* *}$ & $-1,073 * *$ \\
& $(0,574)$ & $(0,000)$ & $(0,000)$ & $(0,000)$ & $(0,001)$ \\
$\mathrm{R}^{2}$ & 7,3082 & 18,915 & 22,658 & 11,264 & 12,148 \\
Adj $\mathrm{R}^{2}$ & $(0,047)$ & $(0,000)$ & $(0,000)$ & $(0,000)$ & $(0,000)$ \\
\hline
\end{tabular}

**signifikan pada taraf nyata $5 \%$

* signifikan pada taraf nyata $10 \%$

Berdasarkan hasil estimasi tersebut dapat dilihat bahwa pada model produk HS 4001 (Natural rubber balata gutta-percha etc) terdapat dua variabel yang berpengaruh yaitu perbedaan GDP per kapita dan Trade/GDP. Variabel yang berpengaruh signifikan pada taraf 5\% untuk produk 4809 (Carbon self-copy paper etc roll of width $>36 \mathrm{~cm}$ ) adalah perbedaan GDP per kapita, nilai tukar riil dan jarak ekonomi. Pada model produk HS 0801 (Brazil nuts cashew nuts \& coconuts) terdapat tiga variabel yang berpengaruh signifikan pada taraf 5\% yaitu perbedaan GDP per kapita, tarif dan jarak ekonomi. Pada model produk HS 5509 (Yarn of synth staple fibre not put for retail sale) perbedaan GDP per kapita, nilai tukar riil, tarif, trade/GDP dan jarak ekonomi berpengaruh signifikan pada taraf 
nyata 5\%. Adapun pada model produk HS 4420 (Wood marquetry \& inlaid wood) perbedaan GDP per kapita, tarif dan jarak ekonomi berpengaruh signifikan pada taraf nyata 5\%, sedangkan Trade/GDP berpengaruh nyata pada taraf $10 \%$.

\section{Perbedaan GDP Per Capita}

Variabel perbedaan GDP per kapita merupakan variabel yang signifikan pada taraf $5 \%$ dan memengaruhi nilai ekspor untuk seluruh produk. Hal ini ditunjukkan oleh probabilitas variabel pada masingmasing produk yang memiliki nilai di bawah 0,05 (selang kepercayaan 5\%).

Nilai positif pada variabel perbedaan GDP per kapita sesuai dengan hipotesis Heckscher-Ohlin. Hipotesis Heckscher-Ohlin memprediksi bahwa negara-negara dengan tingkat pendapatan per kapita yang tidak sama akan lebih banyak melakukan perdagangan dibandingkan dengan negara-negara dengan tingkat pendapatan per kapita yang sama (Rahman 2009). Hasil yang positif dari perbedaan GDP per kapita dapat digunakan sebagai pendekatan dalam menjelaskan perbedaan faktor endowment yang memiliki efek positif terhadap ekspor (Zarzoso dan Lehmann 2003).

Model Hechseler Ohlin juga disimpulkan pada penelitian Sohn (2005) dalam melihat aliran perdagangan Korea Selatan. Aliran perdagangan Korea Selatan lebih mengacu pada model Hechseler Ohlin dibandingkan dengan model increasing return atau model diferensiasi.

Berdasarkan hasil estimasi diperoleh bahwa adanya kenaikan 1\% perbedaan pendapatan per kapita dapat menaikkan nilai ekspor sebesar 0,475\% produk HS 4001 (Natural rubber balata gutta-percha etc); 0,239\% produk 4809 (Carbon self-copy paper etc roll of width $>36 \mathrm{~cm}) ; 0,817 \%$ produk HS 0801
(Brazil nuts cashew nuts \& coconuts) ; 0,576\% produk HS 5509 (Yarn of synth staple fibre not put for retail sale) dan $0,407 \%$ produk HS 4420 (Wood marquetry \& inlaid wood caskets \& cases or cutlery of wood). Intepretasi di atas berdasarkan asumsi ceteris paribus atau faktor yang lain dianggap tetap.

\section{Nilai Tukar Riil}

Variabel nilai tukar riil berpengaruh signifikan untuk produk 4809 (Carbon self-copy paper etc roll of width > $36 \mathrm{~cm}$ ) dan HS 5509 (Yarn of synth staple fibre not put for retail sale) pada taraf nyata $5 \%$ dan bertanda positif. Apabila terdapat kenaikan nilai tukar riil maka mencerminkan harga barangbarang domestik suatu negara relatif lebih murah dibandingkan dengan harga barang-barang luar negeri. Hal ini dapat mengakibatkan peningkatan ekspor negara tersebut. Hasil estimasi menunjukkan bahwa kenaikan $1 \%$ nilai tukar riil dapat meningkatkan nilai ekspor sebesar 2,519\% untuk produk 4809 (Carbon self-copy paper etc roll of width > $36 \mathrm{~cm}$ ) dan $0,749 \%$ produk HS 5509 (Yarn of synth staple fibre not put for retail sale) ceteris paribus.

Nilai tukar riil tidak memberikan pengaruh terhadap nilai ekspor untuk produk HS 0801 (Brazil nuts cashew nuts \& coconuts) produk HS 4001 (Natural rubber balata gutta-percha etc) dan produk HS 4420 (Wood marquetry \& inlaid wood; caskets \& cases or cutlery of wood). Hasil estimasi penelitian Tenreyro (2007) terhadap beberapa negara menghasilkan kesimpulan bahwa nilai tukar tidak memiliki pengaruh signifikan terhadap ekspor. Ekanada (2004) menyimpulkan bahwa fluktuasi nilai tukar dan volatilitas nilai tukar rupiah memiliki elastisitas yang berbeda pada setiap nilai ekspor komoditi. Pengaruh ini dapat saja signifikan atau bahkan tidak signifikan sama sekali. 


\section{Tarif}

Variabel tarif memberikan pengaruh negatif dan signifikan pada taraf 5\% untuk tiga produk. Hasil analisis menunjukkan bahwa penurunan $1 \%$ tarif dapat menaikkan nilai ekspor sebesar 0,68\% untuk produk HS 0801 (Brazil nuts cashew nuts \& coconuts); 0,65\% produk HS 5509 (Yarn of synth staple fibre not put for retail sale) dan 0,46\% produk HS 4420 (Wood marquetry \& inlaid wood; caskets \& cases or cutlery of wood).

Kenaikan atau penurunan tarif tidak memberikan pengaruh signifikan bagi nilai ekspor produk HS 4001 (Natural rubber balata gutta-percha etc) dan produk 4809 (Carbon self-copy paper etc roll of width > $36 \mathrm{~cm}$ ). Hal ini dapat dijelaskan karena tarif pada produk HS 4001 (Natural rubber balata guttapercha etc) tersebut relatif sudah rendah di bawah $10 \%$ bahkan negara Peru sudah menerapkan tarif 0 (nol)\%. Sedangkan untuk produk 4809 (Carbon self-copy paper etc roll of width > 36 cm) tarif relatif stabil pada periode penelitian dan Uruguay merupakan negara yang menerapkan 0 (nol)\% tarif.

\section{Trade/GDP}

Variabel

Trade/GDP

memberikan pengaruh yang signifikan untuk produk HS 4001 (Natural rubber balata gutta-percha etc) dan produk HS 5509 (Yarn of synth staple fibre not put for retail sale) pada taraf nyata $5 \%$. Sedangkan pada produk HS 4420 (Wood marquetry \& inlaid wood; caskets \& cases or cutlery of wood) berpengaruh pada taraf nyata $10 \%$. Adapun pada produk 4809 (Carbon self-copy paper etc roll of width > $36 \mathrm{~cm}$ ) variabel ini tidak berpengaruh signifikan.

Variabel Trade/GDP bernilai positif yang menunjukkan bahwa semakin terbukanya suatu negara di kawasan Amerika Selatan terhadap perdagangan dapat meningkatkan nilai ekspor komoditas ekspor prospektif Indonesia. Berdasarkan hasil estimasi dengan menyelaraskan intepretasi dalam satuan logaritma natural (ln) seperti halnya pada variabel tarif, apabila terdapat peningkatan Trade/GDP sebesar $1 \%$ (ceteris paribus) maka dapat meningkatkan nilai ekspor sebesar 0,732\% untuk produk HS 4001 (Natural rubber balata gutta-percha etc). Kenaikan 1\% Trade/GDP untuk produk HS 5509 (Yarn of synth staple fibre not put for retail sale) dapat menaikkan nilai ekspor sebesar 0,320\% dan untuk produk HS 4420 (Wood marquetry \& inlaid wood; caskets \& cases or cutlery of wood) dapat meningkatkan nilai ekspor sebesar $0,114 \%$.

\section{Jarak Ekonomi}

Variabel jarak ekonomi berpengaruh negatif dan signifikan pada taraf 5\% untuk produk selain HS 4001 (Natural rubber balata gutta-percha etc). Hasil analisis menunjukkan bahwa meningkatnya $1 \%$ jarak ekonomi (ceteris paribus) akan mengurangi nilai ekspor sebesar 2,884\% untuk produk HS 0801 (Brazil nuts cashew nuts \& coconuts) $1,073 \%$ untuk produk HS 4420 (Wood marquetry \& inlaid wood; caskets \& cases or cutlery of wood) 3,032\% produk HS 4809 (Carbon self-copy paper etc roll of width>36 cm)dan sebesar 1,365\% untuk produk HS 5009 (Yarn of synth staple fibre not put for retail sale).

\section{KESIMPULAN DAN SARAN}

\section{Kesimpulan}

1. Performa perdagangan IndonesiaPeru dilihat dari neraca perdagangan menunjukkan performa yang semakin meningkat. Hal ini dapat mendukung kerjasama bilateral Indonesia-Peru pada masa yang akan datang. 
2. Produk ekspor prospektif yang dapat dikembangkan Indonesia dalam perdagangan bilateral ke Peru adalah produk HS 4001 (Natural rubber balata guttapercha etc), produk HS 4809 (Carbon self-copy paper etc roll of width > $36 \mathrm{~cm}$ ), produk HS 0801 (Brazil nuts cashew nuts \& coconuts), produk HS 5509 (Yarn of synth staple fibre not put for retail sale) dan produk HS 4420 (Wood marquetry \& inlaid wood; caskets \& cases or cutlery of wood). Berdasarkan hasil analisis IIT menunjukkan bahwa hanya produk HS 5509 (Yarn of synth staple fibre not put for retail sale) dan HS 0801 (Brazil nuts cashew nuts \& coconuts) yang memiliki integrasi lemah sedangkan produk lain tidak terintegrasi.

3. Terdapat perbedaan faktor-faktor yang memengaruhi aliran perdagangan ekspor pada lima produk ekspor prospektif Indonesia ke Amerika Selatan. Perbedaan GDP per kapita dan Trade/GDP merupakan faktor yang berpengaruh bagi nilai ekspor produk HS 4001 (Natural rubber balata gutta-percha etc). Aliran perdagangan produk HS 4809 (Carbon self-copy paper etc roll of width> $36 \mathrm{~cm}$ ) dipengaruhi oleh perbedaan GDP per kapita, nilai tukar riil dan jarak ekonomi. Faktor-faktor yang memengaruhi aliran perdagangan ekspor produk HS 0801 (Brazil nuts cashew nuts \& coconuts) ke Amerika Selatan adalah perbedaan GDP per kapita, tarif dan jarak ekonomi. GDP per kapita, nilai tukar riil, tarif, trade/GDP dan jarak ekonomi merupakan faktor-faktor yang memengaruhi nilai ekspor produk
HS 5509 (Yarn of synth staple fibre not put for retail sale). Sedangkan perbedaan GDP per kapita, tarif, jarak ekonomi dan Trade/GDP merupakan faktor yang berpengaruh terhadap nilai ekspor produk HS 4420 (Wood marquetry \& inlaid wood; caskets \& cases or cutlery of wood).

\section{Saran}

1. Masih diperlukan peningkatan daya saing bagi komoditas ekspor ke Peru sehingga persentase jumlah komoditas yang memiliki daya saing (indikator RCA) dan termasuk kategori rising star dapat ditingkatkan.

2. Berdasarkan hasil analisis IIT, peningkatan diferensiasi produk bagi komoditas ekspor prospektif melalui pengembangan industri manufaktur masih diperlukan.

3. Pengembangan ekspor komoditas prospektif ke kawasan Amerika Selatan perlu ditingkatkan karena memiliki perbedaan GDP per kapita yang cukup besar terutama untuk negara Chili, Argentina, Brazil, Uruguay dan Venezuela.

4. Tarif merupakan faktor yang memengaruhi nilai ekspor produk HS 0801 (Brazil nuts cashew nuts \& coconuts), produk HS 5509 (Yarn of synth staple fibre not put for retail sale) dan HS 4420 (Wood marquetry \& inlaid wood; caskets \& cases or cutlery of wood) sehingga masih perlu mendapatkan perhatian penurunan tarif dalam negoisasi perdagangan bilateral.

5. Nilai tukar riil berpengaruh nyata terhadap produk HS 5509 (Yarn of synth staple fibre not put for retail sale) dan HS 4809 (Carbon selfcopy paper etc roll of width > 36 $\mathrm{cm}$ ) sehingga diperlukan peran pemerintah dalam menjaga kestabilan nilai tukar. 


\section{DAFTAR PUSTAKA}

Austria, M.S. 2004. The Pattern of Intra-ASEAN Trade in the Priority Goods Sectors. Final Main Report 3/006e: 1-176.

Direktorat Kerjasama Perdagangan Internasional Kemendag. 2012. Laporan Bulanan Juli 2012. Jakarta

Ekananda, M. 2004. Analisis Pengaruh Volatilitas Nilai Tukar pada Ekspor Komoditi Manufaktur di Indonesia Penerapan Estimasi dengan Menggunakan Distribusi Lag Poissons pada Persamaan Non Linier Seemingly Unrelated Regression. Buletin Ekonomi Moneter dan Perbankan Bank Indonesia. September 2004 : 197235.

Estherhuizen, D. 2006. Measuring and Analyzing Competitiveness in the Agribusiness

Sector: Methodological and Analytical Framework. University of Pretoria.

Grimwade, N. 2000. Intra Industry Trade and Specialization. Chapter 3 in International Trade New Pattern of Trade, Production and Investment. $\quad 2^{\text {nd }}$ edition. TJ International Ltd. Great Britain

Kementerian Perdagangan. Statistik Perdagangan Desember 2013. Kementerian Perdagangan RI. Jakarta.

Kementerian Perdagangan. Laporan Kinerja Menteri Perdagangan RI Tahun 2012. Pushaka (c) 2013. Jakarta.

Kementerian Pertanian. 2013. Penandatanganan MoU Bidang Pertanian Antara Pemerintah
Indonesia dan Peru http://pusatkln.setjen.pertanian.go .id [diakses tanggal 22 Desember 2014].

Portocarrero, H.E.R. 2013. Banyak yang Bisa Ditawarkan Indonesia [ulasan]. Majalah Direktorat Jenderal Amerika dan Eropa Kementrian Luar Negeri RI, Peluang 2 (2013) : 10-12. Jakarta.

Rahman MM. 2009. Australia's Global Trade Potential: evidence from the gravity model analysis. Oxford Business \& Economics Conference Program. ISBN : 978-0-9742114-1-9. Oxford University. United Kingdom

Sanborn CA Yong A. 2013. Peru's Economic Boom and the Asian Connection. Woodrow Wilson Center for Scholars. Washington DC.

Shepherd B. 2013. The Gravity Model of International Trade : A User Guide. ARTNeT Gravity Model Initiative. ESCAP-United Nations. Thailand.

Sohn CH. 2005. Does The Gravity Model Explain South Korea's Trade Flows? The Japanese Economic Review. 56 (4) : 417430.

Tenreyro S. 2007. On the Trade Impact of Exchange Rate Volatility. Journal of Development Economics. Vol 82 (2): 485-508.

Zarzoso IM Lehmann FN. 2003. Augmented Gravity Model : An Empirical Application to Mercosur-European Union Trade Flows. Journal of Applied Economics. 6 (2): 291-316. Gottingen University. Germany. 